Each paper is followed by an extensive bibliography, together with shortened versions of the discussions which succeed each paper. Although these bring the book up to date, they would have been easier to follow if they had been given under headings similar to those in the chapters.

It is appropriate that the first chapter should be devoted to the target organ of so many toxic substances, namely the liver, and it is encouraging to discover chapters covering hitherto neglected subjects such as the fungal infections, parasites and ophthalmic pathology of rats and mice, but it is disappointing to find that there are no chapters on bacterial diseases, cardiovascular diseases of mice and diseases of the lymphatic system. Although pneumonia and virus infections are adequately treated, salmonellosis, which is probably the commonest infection of these animals, is given barely one page, and even then only in passing.

The advantages of using specific pathogen free or disease free animals are amply demonstrated throughout and, in particular, the part that inapparent disease may play in invalidating experimental results.

Several pleas are also made for the increased use of defined inbred strains or, as one author put it, "inbred mice are as indispensable to the biologist as pure chemicals are to the chemist". Yet, even today, people still ask for white mice!

There is little doubt that this book will be invaluable to both the animal pathologist and the producor of laboratory rats and mice; the former because it may enable him to decide whether any lesions that are found after death are due to the experimental procedures or naturally occurring disease, and the latter because the prompt recognition of disease and its diagnosis saves a great deal of time and money.

Although neither of the editors, both well known in their field, has contributed any of the papers, they feature prominently in the discussions, and must be congratulated for the excellent presentation, the many very good illustrations and the more than adequate index.

It is hoped that a companion volume will soon appear, covering the pathology of other species. JоHN BLEBY

\section{RANGE OF MOLLUSCS}

\section{Molluscs}

By J. E. Morton. (Biological Sciences.) Fourth, revised edition. Pp. 244. (London: Hutchinson and Co. (Publishers), Ltd., 1967.) 13s. 6 d. net.

WHEN I was a student, work on molluses consisted of a largely anatomical survey related to hypothetical ancestral forms caught up in a variety of posturings from which some emerged with coiled shells, some with straight shells, some with none, some with torsion, some without. There was no hint, or hardly any hint, of the rich and exciting results of the work on functional anatomy which were to emerge later, although some of Orton's observa. tions (which began it all) had already been long published and the first fruits of Yonge's magnificent extended study of these animals had been gathered.

Molluses are unusual animals, and, at least for some people, exciting ones. Their chief attraction is the quite extraordinary way in which they retain their charac. teristics of anatomy - and even of function-- no matter how mueh their bodies become contorted in pursuit of some special adaptation, and it is the curious intimato mixture of anatomy and functioning in relation to adapta. tion for life in a particular niche that makes them such an absorbing study. It is a never ending study, too, for year after year something unusual is discovered even about the most ubiquitous type. Despite this, and despite the recent resurgence of interest in the phylum, there is at present only one book which has attempted a summary of modern malacological work at undergraduate level:
Morton's Molluscs, first published in 1958 and now appearing in a fourth, revised edition. The text has been extended to incorporate new material-most significantly, information about Neopilina, still not known when the first edition appeared, though Morton had bad luck here in being just too early to include it, and an expanded treatment of Wells' work on cephalopod behaviour. Perhaps the change for which most readers will be grateful is the increased number of illustrations, most in the Morton idiom, though still, I find, small considering the page size, and sometimes (as in Fig. 29, page 137) rather too complex.

There are some things I miss: I would like in particular to see an account of how the molluscan radula-a major feature of the group-works, not just of what it looks like; there is a lot of interesting work done on the behaviour of molluses other than cephalopods though not referred to here; and the account of boring by muricacean neogastropods oddly omits all reference to the most extensive and experimentally critical work on this topic-that of Carriker.

These, however, are minor carpings aroused in my mind by not finding perfect a book which I should like to be perfect. Morton has made a bold and outstandingly successful attempt to get all the really important facts about the living molluse into very brief compass. My students tell me that they enjoy it and that he has succeeded in adding to his information some of the fascination which he, I know, and most malacologists have found in the study of molluses. But perhaps the credit for this should really go to the molluse and not to the author.

A. Graham

\section{LIFE IN WATER}

\section{Oceanography and Marine Biology}

An Annual Review. Vol. 4. Edited by Harold Barnes. Pp. 505. (London: George Allen and Unwin, Ltd., 1966.) 105s. net.

THE fourth edition of this annual review continues to navigate the hazardous waters surrounding a journal that attempts to serve a number of different disciplines, united by a common interest in the sea. Paradoxically, the biggest problem that it has to overcome is that which presumably it is intended to promote, namely, the exchange of ideas at the research level between the physical and biological sciences.

The first four reviews cover different aspects of physical oceanography. The article by W. Krauss on internal waves in the sea is a mathematical treatment of data collected at sea, and, apart from acknowledging the international reputation of the author in this field, comment is beyond my ability. In contrast, the paper by $K$. Wyrtki on the oceanography of the eastern Equatorial Pacific is a readable and informative discussion of the hydrography of this ocean, with particular attention paid to the problems raised by the recently discovered Equatorial undercurrent. This section is completed by an aceount of conditions governing the formation of ice in the Baltic by E. Paluso, and a record of some of the initial difficulties oxperienced in the organization of the international Indian Ocean expedition by $\mathrm{R}$. Currie.

The origin, identification and distribution of gelbstoff in the sea are discussed by $K$. Kalle. This non-specific term is applied to a heterogeneous group of yellow compounds derived from the degradation of marine algae and also from humic compounds of terrestrial origin. This is supplemented by a review of the extracellular products of algae by G. E. Fogg, dealing with compounds of smaller molecular weight which are more often studied in culture media. The important contribution of micro-organisms to the fertility of the sea is generally realized but little understood, and an interesting account of marine psychro- 